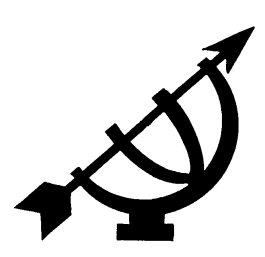

\title{
A perspective on balancing the legal and moral rights and responsibilities of HIV positive and HIV negative individuals
}

\author{
C.S. le Roux \\ Department of Further Teacher Education \\ University of South Africa \\ PRETORIA \\ E-mail:Irouxcs@unisa.ac.za
}

\begin{abstract}
A perspective on balancing the legal and moral rights and responsibilities of HIV positive and HIV negative individuals

In South Africa HIVIAIDS is no longer being described as an epidemic, but rather as a pandemic due to the devastating impact that it is having on all spheres of societal life. HIVIAIDS is not exclusively a health issue - it has also become a matter of political, economic, moral and legal concern and debate. One of the issues that consequently needs to be addressed is the establishment of an effective and equitable approach to dealing with HIVIAIDS issues - based on principles of justice and equity - that acknowledges the legal and moral rights and duties of both HIV positive and HIV negative persons. Legislation is a useful instrument in protecting and upholding the rights of citizens irrespective of their HIV status. However, because HIVIAIDS has an underlying socio-moral dimension it follows that important processes in understanding the epidemic and in establishing perspectives on confronting the issue include the identification of and enquiry into the perceived moral rights and obligations of those affected by the disease. Furthermore, in a country where Christianity is one of the predominant religions with distinctive moral tenets, a Christian community stance on HIVIAIDS issues should be probed.
\end{abstract}

\section{Introduction}

In South Africa HIV/AIDS is no longer described as an epidemic, but as a pandemic. Some go as far as declaring it a holocaust due to the apparent inability to arrest the spread of the disease that threatens to decimate the country's population. It is accepted that approximately $10 \%$ of the population, or about 4.2 million people, are currently HIV positive. 
However, in the high risk group - those between 18 and 29 years of age - the average infection rate is estimated at $20 \%$ and possibly even higher. It is conjectured that about 2500 new infections occur daily and six million people are expected to die from AIDS in the next decade (Lovell, 2000; Serenata, 2000).

The impact that HIV/AIDS has on all facets of society indicates that it can no longer be viewed exclusively as a health issue - especially too, since no medical solution to HIV/AIDS is imminent. It is now accepted that HIV/AIDS is a bio-psycho-social disease and consequently not only governments, but also individual citizens have an obligation to become involved in dealing with the disease and its effect (AIDS Impact, 2001). In South Africa, the government has - on the basis of its constitutional obligation to protect its citizens from threats to life and liberty and to afford all citizens equal concern and respect - passed legislation that relates specifically to the protection of the rights of seropositive (HIV positive) individuals. Despite this legislation and attempts to halt the spread of the disease through health education programmes, the desired impact has not been achieved and society is now challenged to adopt a moral or ethical approach to dealing with and stopping the spread of the disease. This seems to be a logical offshoot given the character of the disease as well as the general nature of its transmission.

The current HIV/AIDS discourse seemingly focuses exclusively on the plight of the seropositive individual with the HIV negative individual receiving little or no particular consideration. Much has been written on the legal rights of HIV positive individuals, but little by comparison has been written on the legal or moral obligations of those with HIV/AIDS or the legal and moral rights and obligations of those who are HIV negative. Nonetheless, when attempting to deal with HIV/AIDS from a moral perspective, a distinctive question arises: "Whose morality?" In modern society where a human rights culture predominates, morality is ostensibly dichotomous - on the one hand there seems to be a secular and on the other, a religious morality.

It is the intention of this article to consequently provide a perspective on current legislation as it pertains to HIV/AIDS matters, to probe the issue of the perceived moral rights and responsibilities of seropositive and HIV negative individuals and to provide a succinct perspective on how a Christian could view moral responsibility in relation to HIV/AIDS. To ensure accord in understanding, a synopsis of the terminology as it relates to this discourse is outlined below. 


\section{Clarification of concepts}

\subsection{Legal and moral}

According to Handler (1994:298; see Ballentine's Law Dictionary) legal means "according to law; in accordance with statute; by means of judicial proceedings; that which is inferred or presumed by the law". In lay terms, the Reader's Digest Universal Dictionary (RDUD) (1987:878) defines legal as "pertaining to or concerned with law; authorised by or based on law; established by law; statutory; recognised or enforced by law rather than by equity". The term moral pertains to "virtue or right conduct relating to the distinction between right and wrong" (Handler, 1994:346) and could be termed an ultimate standard of ideal human conduct.

Moral and legal differ: human beings decide for themselves what is moral (good) and immoral (bad) in human action or character and morality does not involve formal sanctions. Moral consideration is consequently that which is good in conscience. Law, on the other hand is created by the State and is enforced by its authority (RDUD, 1987:1003; Handler, 1994:347).

\subsection{Ethics and ethical}

Ethics described in legal terms is "a code of moral principles and standards of behaviour for people in professions such as law or medicine" (Handler, 1994:172); yet the term is also used to describe a collection of moral principles as clarified by RDUD (1987:527) "being in accordance with the accepted principles of right and wrong governing the conduct of a group". Walker (1980:433; see The Oxford Companion to Law) discusses ethics as moral philosophy and defines it as "the systematic study of the ultimate problems of human conduct". These problems turn chiefly to the issues of the ultimate standard of right conduct; the highest good, or of right and wrong; the motives which prompt right conduct and the sanctions of moral conduct.

\subsection{Just and justice}

According to Handler (1994:287) just means "right or fair according to law; legally right or lawful" while RDUD (1987:836) describes just as "honourable and fair in one's dealings and actions; consistent with moral right; fair, equitable; properly due or merited; legally valid or correct; lawful; suitable". Walker (1980:689) states that justice is "a moral value commonly considered to be the end which law ought to try to attain, which it should realize for the men whose conduct is governed by law and which is the standard or measure or criterion of goodness in law and 
conduct by which it can be criticized or evaluated. Justice is what is pleasing or approved".

\subsection{Secularism and humanism}

The definitions of the terms related to secularism are included because of the close relationship between these terms and humanism which forms the basis of an understanding of a human rights culture. According to The Shorter Oxford English Dictionary on Historical Principles (SOEDHP) (1978:1926) secularism is the "doctrine that morality should be based solely on regard to the well-being of mankind in the present life, to the exclusion of all considerations drawn from belief in God or in a future state" while the term secularisation is defined as "the giving of a secular or non-sacred character or direction to [art, studies, etc. ]; the placing [of morals] on a secular basis". According to Webster's New World Dictionary (1976:463) humanism is "a philosophical movement that holds that man can be moral and find meaning in his life through reason, without the aid of supernatural religion". From the preceding it is clear that a divine being has no place in the concept of secular or humanistic morality and that man alone determines what is moral, good and meaningful.

\subsection{Religion and Christian}

The SOEDHP (1978:1788) defines religion as

... action or conduct indicating a belief in, reverence for, and desire to please, a divine ruling power; the exercise or practice of rites or observances implying this. A particular system of faith and worship. Recognition on the part of man of some higher unseen power as having control of his destiny and as being entitled to obedience, reverence and worship; the general mental and moral attitude resulting from this belief.

According to the Bible (Acts 11:26) Christian refers to a "follower of Christ" and such a person believes in, trusts, loves and desires to obey and follow Jesus Christ (John 10:14, 27) and seeks to glorify and honour God in everything that he or she thinks or does (1 Cor. 10:31).

Contrary to secular or humanist views on morality (cf. 2.4) a religious or Christian morality places the divine ruling power central to determining what is moral and how morality should be attained.

\subsection{Rights}

It is interesting to note that Walker (1980:1070) describes right as a much ill-used and over-used term! The discussion of the concept leads further to drawing a distinction between moral and legal rights with the 
former being claims which, it is asserted, should by natural justice or principles of morality, be recognised and protected, whereas the latter may or may not have any moral basis, but are in fact recognised and protected by the particular legal system in question. The latter rights may be created or taken away by legislation or be recognised or declared not to exist by courts. Further support for this exposition that points to the moral and legal nature of rights is found in Handler (1994:483) where right is defined as "in accord with law, morality and justice; correct, appropriate. In a purely legal sense, a just or valid claim recognised or granted by the law and enforced by the law. In a more general sense that which is morally and ethically proper".

The following definitions of the concept serve to clarify further its meaning in relation to the theme of this article. The SOEDHP (1978: 1831) states that right is "a justifiable claim, on legal or moral grounds; a legal, equitable or moral title or claim to the enjoyment of privileges or immunities" while according to Machan (1989:2) a right "seems to be a social condition that ought to be maintained, a moral principle pertaining to aspects of social life". Rights are described as being relational - a right pertains to the moral responsibilities that arise among humans through their cohabitation and interaction with one another. The idea of a [human] right is that it is a social construct that reflects social acknowledgements of individual and communal basic and perceived needs in a particular historical period. In short, [human] rights are statements of human needs (Wronka, 1992:22).

Commonalities found in these explanations are that a right is

- bound in the context of social morality and law - one is legally and morally obliged to respond to the justifiable claims or social needs of others;

- inherently relational and cannot be enjoyed in isolation.

However, rights are not absolute and in certain instances, rights are limited.

\subsection{Limitation of rights}

Rights may not be exercised without any regard for the rights or interests of individuals or society and every right is limited in content and scope. The limitation clause in Section 36 of the Constitution of South Africa (South Africa, 1996b) makes it possible for a fundamental right to be limited by means of a legal rule that applies to all citizens equally. Limitations to rights are possible if they are reasonable and justifiable in an open and democratic society based on human dignity, equality and 
freedom. The relevant factors that need to be taken into consideration when a limitation of a right is contemplated include:

- the nature of the right;

- why it is important to limit the right;

- what the purpose and nature of the limitation is;

- whether there are not perhaps other less restrictive means to achieve that purpose.

If, in the light of these factors, the limitation could be described as reasonable and justifiable, it will be permitted in terms of the Constitution (Stoop, 1997:8; 60-61).

\subsection{Duties, obligations and responsibilities}

As alluded to in the preceding analysis of the concept rights, three terms namely duties, obligations and responsibilities are frequently used conjointly in relation to rights. As with rights where a distinction is made between legal and moral rights, so too, a distinction is made between legal and non-legal (moral or natural) duties, obligations and responsibilities. The distinction implies that, while a moral obligation is not enforceable, a legal one is (Handler, 1994:347; Walker, 1980:898).

Duty is described as "a legal obligation whether imposed by common law, statute, court order or contract; any obligation or responsibility" (Handler, 1994:156) or as "a legal disadvantage, that which is owed or due to another and should be satisfied" (Walker, 1980:385).

A moral obligation could be said to emanate from moral law - the law of conscience (ethics, morality) and as such is a commitment arising from ethical motives as distinguished from legal obligation. Sometimes an obligation, e.g. to save life, to care for persons in need (e.g. AIDS sufferers) could be a moral or even a religious one with no legal obligation entailed (Handler, 1994:347; Walker, 1980:898).

Moral and legal duties, obligations and responsibilities are thus not wholly equivalent. On the one hand, legal obligations are exacted by law and those who hold the obligation are legally accountable. Moral obligations arise from a sense of duty, by conscience, social custom and involve personal accountability to act without superior authority or guidance (RDUD, 1987:480, 1066, 1305). 


\subsection{Equality}

Equality is defined as "the quality of persons being all of the same standard or level and all treated alike" (Walker, 1980:423). In South African law, equality includes the full and equal enjoyment of rights and freedoms as contemplated in Section 9 of the Constitution (South Africa, 1996b). It includes de jure and de facto equality and also equality in terms of outcomes (South Africa, 2000). Central to this principle is the notion that each person within a community is entitled to and should be afforded equal respect, concern, treatment and protection.

However, as explained by Walker (1980:423), equality of rights does not require or justify that all should have the same quantity of rights: all persons have equal rights, but not rights to equal things. Furthermore, equality is not a standard to be rigidly applied - although deviations from equality require rational justification - and it can happen that for obvious or special reasons, the actual quality and extent of the rights depend on the individual and the individual's capacity and conduct and could differ from one individual to the next. According to Erin and Harris (1993:166), in the context of the AIDS pandemic, the principle of equality is disparaged if one does not actively seek to afford all non-infected citizens what protection against infection there is, or if one does not provide seropositive individuals with adequate care for their symptoms and therapy as and when it becomes necessary and available.

\subsection{Discrimination}

Discrimination means any act or omission, including a policy, law, rule, practice, condition or situation that directly or indirectly

- imposes burdens, obligations or disadvantage on; or

- withholds benefits, opportunities or advantages from any person on one or more of the prohibited grounds (South Africa, 2000)

The prohibited grounds of discrimination are

- race, gender, sex, pregnancy, marital status, ethnic or social origin, colour, sexual orientation, age, disability, religion, conscience, belief, culture, language and birth; or

- any other ground where discrimination based on that other ground (i) causes or perpetuates systemic disadvantage; (ii) undermines human dignity; or (iii) adversely affects the equal enjoyment of a person's rights and freedoms in a serious manner that is comparable to discrimination of a ground in the first paragraph (South Africa, 2000). 
The preceding clarification of salient concepts points inevitably to questions of right and wrong - questions of just, ethical behaviour and adherence to moral principles. In the war against HIV/AIDS it is essential that South Africans act responsibly, within the parameters of the country's laws, but also with integrity exemplifying moral behaviour towards attaining the moral good.

\section{Legislation in South Africa and how it applies to the issue of the rights and responsibilities in relation to HIV/AIDS}

Sections 9 and 10 of the Constitution of South Africa (South Africa, $1996 \mathrm{~b})$ protect the right to equality and freedom from unfair discrimination and the right to human dignity of all citizens - regardless of their HIV status. Both the State and its citizens are obliged to respect these fundamental rights. In addition, Section 14 addresses the right to privacy and it consequently follows that all persons with HIV or AIDS have a right to privacy concerning their HIV/AIDS status. Accordingly there is no general legal duty to disclose one's HIV status to one's employer, to other employees, friends or relatives.

Legislation that specifically addresses aspects of HIV/AIDS issues include the following:

- Labour Relations Act No. 66 of 1995 (South Africa, 1995) that states that employees with HIV/AIDS may not be dismissed simply because they are HIV positive or have AIDS. However, where there are valid reasons related to their capacity to continue working and fair procedures have been followed, their services may be terminated.

- Employment Equity Act No. 55 of 1998 (South Africa, 1998) that provides that no person may be unfairly discriminated against on the basis of their HIV status and that no employee or applicant for employment may be required by their employer to undergo an HIV test to ascertain their HIV status.

- Occupational Health and Safety Act No. 58 of 1993 (South Africa, 1993a) in terms of which an employer is obliged to provide as far as is reasonably practicable, a safe working environment and this may include ensuring that the risk of occupational exposure to HIV is minimised. Similar provisos are contained in the Mine Health and Safety Act No. 29 of 1996 (South Africa, 1996a).

- Mine Health and Safety Act No. 29 of 1996. Employees who are infected with HIV as a result of an occupational exposure to infected blood or bodily fluids are entitled to apply for benefits in 
terms of the Compensation for Occupational Injuries and Disease Act No. 130 of 1993 (South Africa, 1993b).

- Promotion of Equality and Prevention of Unfair Discrimination Act No. 4 of 2000 (South Africa, 2000) aimed at the eradication of social and economic inequalities, the upholding of values of human dignity, equality, freedom and social justice in a united, non-racial and non-sexist society. However, a key excision in this Act is the absence of a clause that would make it illegal to discriminate against persons infected with HIV or AIDS. The insurance companies were the dominant group petitioning this step. It was argued that if discrimination against persons with HIV/AIDS was not permitted insurance companies would be forced to give life insurance to people carrying the infection thereby making it impossible for them to remain in business (Lovell, 2000).

Section 34 of this Act states that in view of the overwhelming evidence of the impact on society and link to systemic disadvantage and discrimination on the grounds of inter alia HIV/AIDS status, special consideration must be given to its inclusion on these grounds in the definition of "prohibited grounds" (cf. 2.10 above) which is referred to in the definitions introducing the Act. The Equality Review Committee was consequently mandated to investigate and make recommendations to the Minister in this regard during the course of 2001.

On the other hand, Section 18 of the Constitution of South Africa (South Africa, 1996b) addresses the right to freedom of association and gives individuals the right to associate with whomever they wish. Legislation addressing HIV/AIDS is silent on the uninfected individual's right to avoid associating with those who are seropositive if so desired. It could be argued that since it is a HIV negative person's right to avoid infection, that person may lawfully choose to avoid contact with HIV positive individuals if they were to believe that by so doing, they would be averting the possibility of infection. However, this right could only be effected if the HIV status of individuals were known. It could be argued though that the seropositive individual's right to freedom from discrimination or to privacy could be limited by the uninfected person's right to freedom of association and vice versa. It could further be asked whether the same argument would apply to the HIV negative person's inalienable right to life?

Examples of the State's view in relation to the protection of the rights of all citizens have been outlined. The question that next arises is whether there are moral duties and rights - other than the legal duties and rights 
enshrined in legislation - applicable to those who are HIV positive and those who are not infected.

\section{A perspective on the moral rights and responsibilities of HIV positive individuals}

Probably one of the greatest dilemmas facing seropositive individuals is that they lose, in a certain sense, their identity when their seropositive status is divulged. They are no longer seen as, for example, the young, outgoing, confident individual, but as the seropositive person - the person with HIV/AIDS. For this reason, legislation was passed that ensures that the HIV positive person has the right to privacy and is not obliged to divulge information regarding HIV status. Likewise, discrimination against HIV positive individuals is expressly prohibited.

Ensuing questions that arise relate to the moral grounds on which the claim and need to exercise these rights to privacy and freedom from discrimination are based. The three primary concerns competing in this debate are the seropositive individual's right to confidentiality; the State's - and general public's - desire to curb the spread of the disease; and the personal desire of the uninfected person to be protected from infection. In this context the balancing of seropositive individuals' rights against broader societal rights and the issue of whether there are special rights or duties arising from seropositive status, are subsequently examined.

\subsection{The perceived moral rights of HIV positive individuals}

Literature abounds with accounts indicating that the disclosure of seropositive status generally causes the HIV positive individual a great deal of emotional, social and economic harm resulting in social isolation, a loss of self-esteem, of employment or employability, of insurance or insurability or housing. Stigmatisation arising from such disclosure is commonplace, particularly when the existence of the HIV infection reveals the person's unconventional sexual orientation, promiscuity, or use of illegal drugs (Gostin, 1996). Persons who are seropositive have the legislated right not be subjected to any form of unfair discrimination also that which is based on fear or prejudice - and consequently society is legally obliged to treat these individuals with dignity and respect. It could be argued that society also has a moral obligation in this regard. Central to affording persons human dignity, is the need to acknowledge and respond to the needs of those people and in the case of seropositive individuals, their emotional, economic, medical and spiritual needs. Put differently, the justification for acquiescing to the rights of those in need should depend less on rationality and more on the idea of responding to the moral obligation arising from conscience to respond to calls to meet 
basic human needs and by so doing, afford human dignity to those in need.

\subsection{The perceived moral responsibilities of HIV positive individuals}

It seems uncontentious to assert that all persons have a general obligation to avoid harming or wronging others. However, in the HIV/AIDS dilemma, the seropositive individual's legal right to confidentiality could conflict with the moral imperative to protect others. This is a matter for ethical reflection and is possibly not, in essence, a legal issue.

Those who perceive themselves to be potentially at risk of HIV infection believe that the seropositive person's right to privacy must take second place to their own right to protection from infection and it is consequently asserted that there is an incumbent moral duty on the seropositive individual to forewarn where there is a significant risk of infection 1 (Bennett, Draper, \& Frith, 2000:12; Serovich \& Greene,1993:194). If individuals who know they are or may be seropositive choose not to share this knowledge with sexual partners or forewarn those who come into contact with their blood or bodily fluids of the risks that they might be taking, they will be responsible for subjecting them to the risk of infection and thus the risk of death. In short, a HIV positive person would be responsible for that person's death if - as a result of his/her actions where he/she knowingly or recklessly exposed that person to risk - the person contracts and dies of AIDS (Erin \& Harris, 1993:167). It should be impressed upon persons who know or believe that they are HIV positive that they are morally obliged not to expose others to their body fluids or blood (Bennett et al., 2000:12). However, enforcing this moral obligation in private relationships between individuals hardly seems practicable. Even if the right to protection from infection were enshrined in law, the only feasible way of enforcing it would be by enacting punitive measures against those who neglect their duty to forewarn others of their HIV status and/or compensating those who are the victims of a failure to

1 The disclosure of HIV status presupposes knowledge of one's HIV/AIDS status. Ethically, mandatory testing poses problems - one of which is the challenge to personal autonomy. The practicability and economic viability of prescribed mandatory testing is also questioned. However, those who have reason to suspect that they might be seropositive and those who know they are seropositive should recognise and shoulder their responsibilities to their sexual partners and relevant others. Testing should remain voluntary, but it should be recognized as being morally the right thing to do. Still, it is always helpful if doing the right thing coincides with one's interests (Erin \& Harris, 1993:171) and voluntary testing would be more acceptable were society to adopt a more supportive and compassionate attitude towards those who test positive. 
forewarn. But, from the point of view of the victim, this comes too late (Erin \& Harris, 1993:167-69).

In instances where seropositive individuals purposely disregard their obligation to inform their sexual partners of their HIV status, health professionals who come to know the HIV status of their patients and are aware of the negation to forewarn, could find themselves faced with a personal moral dilemma. It could be argued that exceptions to confidentiality are appropriate when necessary to protect public health or when necessary to protect individuals who are endangered by the actions of HIV positive persons. To resolve this conflict one may ask, "Who has the most to lose?" The importance of consent to disclose, of confidentiality or respecting the right of the seropositive individual to privacy is not discredited, but when other persons' lives are endangered by respecting such principles, the protection of uninfected persons' lives must be an overriding concern (JAMA,1998).

Yet, when the risk of discrimination to which HIV infected persons expose themselves when disclosing seropositivity is considered, it could be contended that the level of risk of transmission could be allowed to influence the strength of the moral obligation to inform others of HIV infection. For example, one may be justified in withholding information about one's HIV status from one's flatmates as long as one minimises the risk of infection, but it is surely morally improper to withhold such information from those with whom one intends, for example, having sexual relations.

It is consequently argued that confidentiality should not be absolute and current legal opinion appears to support the duty to protect. Recently the South African Law Commission was approached to investigate the need for legislation with regard to the "criminalisation" of acts by persons with HIV/AIDS who deliberately or negligently infect others. It was advanced that such persons should be held accountable and in this sense criminal law should provide a measure of protection in the form of deterrence that reflects society's abhorrence of such behaviour (South African Law Commission, 1999a). To give effect to this process, the issue of compulsory HIV testing of persons arrested in sexual offence cases - on a charge or on suspicion - during which HIV might have been transmitted and the right of alleged victims of such offences to be informed of the test results is receiving attention (South African Law Commission, 1999b). Legislative intervention is being debated in view of the high prevalence of HIV coupled with the high prevalence of rape and other sexual offences. Other issues informing the investigation include the utility and limitations of HIV testing; women's international and constitutional rights including 
the victim's rights and the arrested person's constitutional rights - in particular the right to privacy (South African Law Commission, 1999b).

\section{A perspective on the moral rights and responsibilities of HIV negative individuals}

The physical trauma and emotional anguish caused through contracting HIV is considerable and it follows that rational and healthy persons will inevitably do everything in their power to keep from being infected. Since there is no specific legislation regarding the rights of HIV negative individuals, it becomes necessary to reflect on the probable moral rights to which these individuals could lay claim.

\subsection{The perceived moral rights of HIV negative individuals}

The primary moral right which the non-infected person can claim is the right to be protected from HIV infection. Since infection is only possible through exchanging body fluids with HIV positive individuals, the right to be forewarned of seropositivity is absolute. Given the fatal nature of the disease, the claim to this right is indeed to claim the right to life which is probably the paramount right to which any human being can lay claim.

The spread of the life-threatening HIV virus is not independent of individuals' actions and it could be argued that it is the responsibility of HIV negative persons to ensure their protection from infection. However, it is contentious to state emphatically that HIV negative persons have a moral obligation to protect themselves from HIV infection, for although protecting oneself from infection is clearly the prudent thing to do, there may be no moral obligation to do so (Erin \& Harris, 1993:167). It could be argued that the HIV positive person's duty to avoid harming others (e.g. by not infecting others) is primary - thus placing the responsibility to prevent infection on the seropositive individual. Nevertheless, in view of the fact that no effort should be spared in containing the spread of the disease, those who are HIV negative should take energetic measures to remain uninfected, including negotiating with their partner to go for testing to determine HIV status or to insist on the use of condoms.

\subsection{The perceived moral responsibilities of HIV negative individuals}

A duty that HIV negative individuals have towards themselves is to take or negotiate precautionary measures to avoid infection while duties towards their HIV positive counterparts are the obligations that emanate from a judgment of what constitutes integrity of conduct and character doing the honourable or decent thing - and to provide support to these 
persons in meeting their basic needs. This support could be in various guises: creating a climate of tolerance and acceptance in which the human dignity of the seropositive individual is respected; providing medical and health support; providing emotional and counselling support; providing financial and subsistence support and providing adequate palliative care for the terminally ill AIDS patient.

With the foregoing observations, an attempt was made to provide a perspective on the perceived moral responsibilities and rights of individuals in relation to the HIV/AIDS situation. It was noted previously that there is a distinct difference in relation to the meaning of the concept moral when used in secular and in religious terms and the focus now falls on the implications that this fact has for a Christian perspective on the HIV/AIDS issue.

\section{A comparison between a secular and a Christian perspective on dealing with moral issues and equality}

To understand the implications of the foregoing discussion of the perceived moral rights and responsibilities in relation to HIV/AIDS, it is necessary to examine more closely the inherent differences between secular and Christian perspectives of morality and equality and to bear this in mind when perhaps reconsidering what constitutes the moral rights and responsibilities in relation to HIV/AIDS issues.

It could be argued that the prevailing search for a moral consensus based on a common human nature has, since the evolution of a humanist culture which currently predominates in much of the world, replaced the religious basis which was considered to be the indisputable foundation of social morality in certain periods of Christianity. In secular society, instead of a belief in God, concepts of human nature become fundamental in theories of social ethics, human dignity and moral human behaviour. No longer does a sense of morality - the principles that define moral social conduct - emanate from the character of the sovereign triune God, but from the fruits of human reasoning. Likewise, the motivation for moral conduct does not lie in the desire to please or to bring glory and honour to the Creator of humankind, but to fulfil or meet the requirements of that which human reasoning has deemed to be right and good (Pannenberg, 1998).

Christians believe that God is unchangeable (Heb. 13:8) and that it is impossible for God to lie (Heb. 6:18) while it is undisputed that humankind and thus also the reasoning of humankind - is inconstant (cf. 1 Cor. 1:23-25). People are known to be self-serving creatures and conesquently the challenge in defining the principles of moral conduct must of 
necessity be to ensure that these principles are not made subservient to individual preference since there could be a powerful desire to "pick and choose" among what should or should not be a moral principle (Pannenberg, 1998). This could possibly explain the moral crisis of modern secular societies!

Christians reject the dualistic approach to life which divides life into the sacred - in which God has authority - and the secular - which is independent from God. Christians are called to honour this fact in their moral reasoning, i.e. that one moral standard applies to all facets of life. This perspective is in line with the premise that Christians are called to fulfil their divine vocation regardless of whether it is in the "religious" or the "secular" sphere of life. Christian love (not to be equated with unconditional acceptance, since Christian love is ready to accept everyone but at the same time calls sinners to repentance (John 8:11)) is the overarching contribution to Christian morality. This love is not limited to doing the moral good, but has as its aim to bring honour and glory to God - the ultimate experience of Christian fulfilment. It is best remembered too, that doing the morally right thing is not paramount, but doing it for the right reason is.

Furthermore, humanist equality is not the same as Christian equality. According to a Christian understanding of equality humankind have in common the same filiation and the same vocation (1 Tim. 2:3-4) i.e. seeking God and doing His will i.e. living in love towards one another and accepting responsibility for one another (John 15:12; 2 Cor. 5:14; 1 John 4:7). The Christian recognises each individual as part of God's creation and that God loves all equally (John 3:16), but also that God hates sin (Heb. 1:9) and therefore that unrighteous deeds are to be denounced and actively opposed. Conversely, according to humanist equality that which humankind has in common is the right to pursue different ends. It could be said that a Christian will say "I do what I should, I do what I must" while a secular person will say "I do what I want, each one of us is sovereign, each is equal to everyone else; I live as I want and my way of life is equal to everyone else's" (Beneton, 1993). The secular view of equality is much a matter of self-affirmation and implies a self-centred focus on the individual. A Christian perspective is of subservience to one another.

Because HIV/AIDS is inextricably linked to sexual behaviour, it is also necessary to reflect on a Christian perspective of what constitutes acceptable sexual conduct. Christians need to sustain a Biblical commitment to sexual purity i.e not sanctioning homosexuality, fornication or adultery (Thess. 4:3). The secular attitude that produces and condones sexually immoral behaviour rejects God and His Word and are thus 
renounced by God (1 Cor. 6:9). However, final judgement lies with God and Christians are admonished not to judge or condemn (Luke 6:37), but to pursue interpersonal relationships that exemplify love, compassion, selflessness, forgiveness and patience so that such relationships are governed by love and peace (Col. 3:12-15).

Based on the preceding discussions, it can be deduced that a Christian will view the moral rights and responsibilities in relation to the HIV/AIDS crisis somewhat differently from the rest of the world. The implications of the foregoing is that Christians will recognise that they have a unique, and undoubtedly, significant role to play in giving expression to the tenets of the Christian philosophy of life, of Christian love in a world much devoid of love and compassion. Perhaps the HIV/AIDS plight provides the opportunity for Christians to reveal the might of God's sovereign forgiveness and love.

\section{Summary}

The forecast societal impact of HIV/AIDS is incomprehensible since there is no precedent for this pandemic. HIV/AIDS poses primary legal and moral obligations. Enshrined in the Constitution is the recognition of citizens' legal rights that relate inter alia to the right to life, the right to be treated with respect, equality and dignity, the right to privacy and to freedom of association - rights open to particular interpretation by and of specific importance to both seropositive and seronegative individuals.

However, HIV/AIDS is much a social problem and consequently a perspective on the moral rights of seropositive and seronegative persons is also central to understanding the epidemic and to finding ways to halt its course. Although rights may be said to be fundamental, the acknowledgement of the correlative legal and moral obligations in relation to the HIV positive as well as the HIV negative individual could be central to finding solutions to the HIV/AIDS epidemic which apply equitably and fairly to all. When the issue of moral duties is contemplated, the role of Christians to give expression to the tenets of a Christian philosophy of life, Christian love could impact significantly on how moral responsibilities and rights of individuals infected and affected by HIV/AIDS are viewed and concretised. No Christian who lays claim to following Christ's example can ignore the imperative to support those who are affected by HIV/AIDS by being caring and compassionate. Yet, Christians are cautioned to live their lives responsibly, seeking and doing God's will, to respect and comply with Christ's view of marriage and sexuality, and to overcome sin through petitioning Christ's forgiveness for confessed unrighteous actions. Christians are to live an exemplary life 
and to proclaim Christ in such a way that their life serves as an inspiration to all, also to those who have not yet come to know Christ.

It is not intended that this reflection on the issue of balancing the rights and responsibilities of HIV positive and negative individuals should offer a conclusive view on the matter, but that further discourse and debate on this emergency issue which will ultimately affect each one of us however directly or indirectly - should be entered into.

\section{Bibliography}

AIDS IMPACT. Fifth International Conference on the biopsychosocial effects of HIV/ AIDS. 2001. Brighton : United Kingdom.

BALLENTINE'S LAW DICTIONARY: LEGAL ASSISTANT EDITION see HANDLER, 1994.

BENETON, P. 1993. The languages of the Rights of Man. [Available on internet: http://firsthings.com/ftissues/ft9311/articles/Beneton.html] [Date of access: 29:08:2001].

BENNETT, R., DRAPER, H. \& FRITH, L. 2000. Ignorance is bliss? HIV and moral duties and legal duties to forewarn. Journal of Medical Ethics, 26:9-15.

ERIN, C. \& HARRIS, J. 1993. AIDS: ethics, justice, and social policy. Journal of Applied Philosophy, 10(2):165-173.

GOSTIN, L.O. 1996. Confidentiality, privacy and the "right to know". [Available on internet:http://www.ama-assn.org/special/hiv/policy/confide.html] [Date of access: 20:11:2000].

HANDLER, J.G. 1994. Ballentine's Law Dictionary: Legal Assistant Edition. New York : Delmar.

JAMA

see The Journal of the American Medical Association. 1998.

LOVELL, J. 2000. South Africa: South Africa passes anti-discrimination bill. [Available on internet: http://www. africa.com/health/?aid=1fu742io]

[Date of access: 21:11:2000].

MACHAN, T.R. 1989. Individuals and their rights. Illinois : Open Court.

PANNENBERG, W. 1998. When everything is permitted. [Available on internet: http://firsthings.com/ftissues/ft9802/articles/panenber.html] [Date of access: 29:08:2001].

READER'S DIGEST UNIVERSAL DICTIONARY. 1987. Boston : Houghton Mifflin.

RDUD

see Reader's Digest Universal Dictionary.

SERENATA, C. 2000. A profile of HIV/AIDS in South Africa. Paper read at the National Workshop of Relevant Contents for the HIV/AIDS curriculum hosted by the Department of Advanced Nursing Sciences: UNISA. Deputy Director HIV/AIDS \& STD Division. Department of National Health. 25 October 2000.

SEROVICH, J.M. \& GREENE, K. 1993. Perceptions of family boundaries: the case of disclosure of HIV testing information. Family Relations, 42:193-197.

SOEDHP

see The Shorter Oxford English Dictionary on Historical Principles.

SOUTH AFRICA. 1993a. Occupational Health and Safety Act No. 58 of 1993. Pretoria : Government Printers.

SOUTH AFRICA. 1993b. Compensation for Occupational Injuries and Disease Act No. 130 of 1993. Pretoria : Government Printers. 
SOUTH AFRICA. 1995. Labour Relations Act No. 66 of 1995. Pretoria : Government Printers.

SOUTH AFRICA. 1996a. Mine Health and Safety Act No. 29 of 1996. Pretoria : Government Printers.

SOUTH AFRICA. 1996b. Constitution of South Africa Act No. 108 of 1996. Pretoria : Government Printers.

SOUTH AFRICA. 1998. Employment Equity Act No. 55 of 1998. Pretoria : Government Printers.

SOUTH AFRICA. 2000. Promotion of equality and prevention of unfair discrimination Act No. 4 of 2000. Government Gazette 20876. [Available on internet: http://www.acts.co.za/htext_online_pepud.htm] [Date of access: 22:11:2000]

SOUTH AFRICAN LAW COMMISSION. 1999a. Aspects of the law relating to AIDS: the need for a statutory offence aimed at harmful HIV-related behaviour. [Available on internet: http://www.law.wits.ac.za/salc/discussn/hivbehvesum.html] [Date of access: 22:11:2000].

SOUTH AFRICAN LAW COMMISSION. 1999b. Report on compulsory HIV testing of persons arrested in sexual offence cases.

[Available on internet: http://www.law.wits.ac.za/salc/discussn/aidssum.html] [Date of access:22:11:2000].

SPIRIT FILLED LIFE BIBLE. 1991. Nashville : Thomas Nelson.

STOOP, B. 1997. Certificate programme in law. Johannesburg : Butterworths.

THE JOURNAL OF THE AMERICAN MEDICAL ASSOCIATION. 1998. Ethical issues involved in the growing AIDS crisis. [Available on internet:http://www.amaassn.org/special/hiv/policy/amapol.htm] [Date of access:20:11:2000].

THE OXFORD COMPANION TO LAW see Walker. 1980.

THE SHORTER OXFORD ENGLISH DICTIONARY ON HISTORICAL PRINCIPLES: Volume II. 1978. Oxford: Oxford University Press.

WALKER, D.M. 1980. The Oxford Companion to Law. Oxford : Clarendon.

WEBSTER'S NEW WORLD DICTIONARY. 1976. S. v. "humanism". New York : Collins World. p 463.

WRONKA, J.M. 1992. Human rights and social policy in the 21st century. Maryland: University Press of America.

\section{Key concepts:}

Christian duty

HIV/AIDS

moral responsibilities

rights

\section{Kernbegrippe:}

Christelike plig HIV/VIGS

morele verantwoordelikhede regte 